\title{
Praktik Pembiayaan Mudharabah dan Musyarakah terhadap Profitabilitas Bank Umum Syariah di Indonesia
}

\author{
Fena Ulfa Aulia \\ Program Studi Akuntansi Syariah, Fakultas Ekonomi dan Bisnis Islam, IAIN Madura, Indonesia \\ fenaulfa@iainmadura.ac.id \\ Elda Ayu Nabila AJ \\ Program Studi Perbankan Syariah, Fakultas, Ekonomi dan Bisnis Islam, IAIN Madura, Indonesia \\ eldaayunabila12@gmail.com
}

\begin{abstract}
:
This study aims to determine the impact of mudharabah financing and musyarakah financing on the profitability of Islamic commercial banks in Indonesia (2017-2019 period). In this study, using a quantitative approach with the type of associative research. The popolation used is all Sharia Commercial Banks registered in Indonesia. The sampling technique is using the Simple Random Sample technique. The data analysis technique used the classical assumption test (normality test, autocorrelation test, heteroscedasticity test, multicollinearity test), multiple linear regression equation analysis test, and statistical test $(\mathrm{t}$ test, $\mathrm{F}$ test and determination coefficient test). The results showed that both mudharabah and musyarakah financing had a significant and positive effect on profitability (ROA) simultaneously. The partial test results show that mudharabah financing has a significant and positive effect on profitability (ROA), while musyarakah financing has a significant and negative effect on profitability (ROA).
\end{abstract}

Keywords: Mudharabah Financing, Musharaka Financing, and Profitability

\begin{abstract}
Abstrak:
Penelitian ini bertujuan untuk mengetahui dampak pembiayaan mudharabah dan pembiayaan musyarakah terhadap profitabilitas bank umum syariah di Indonesia (Periode 2017-2019). Dalam penelitian ini menggunakan pendekatan kuantitatif dengan jenis penelitian asosiatif. Popolasi yang digunakan adalah seluruh Bank Umum Syariah yang terdaftar di Indonesia. Teknik pengambilan sampel yaitu dengan menggunakan teknik Simple Random Sample. Teknik analisis data menggunakan uji asumsi klasik (uji normalitas, uji autokorelasi, uji heteroskedastisitas, uji multikolinearitas), uji analisis persamaan regresi linear berganda, dan uji statistik (uji t, uji F dan uji koefisien determinasi). Hasil penelitian menunjukkan bahwa pembiayaan mudharabah dan pembiayaan musyarakah secara simultan berpengaruh signifikan dan positif terhadap profitabilitas (ROA). Hasil pengujian secara parsial menunjukkan bahwa pembiayaan mudharabah berpengaruh signifikan dan positif terhadap profitabilitas (ROA), sedangkan pembiayaan musyarakah berpengaruh signifikan dan negatif terhadap profitabilitas (ROA).
\end{abstract}

Kata Kunci: Pembiayaan Mudharabah, Pembiayaan Musyarakah, dan Profitabilitas 


\section{Praktik Pembiayaan Mudharabah dan Musyarakah terhadap Profitabilitas Bank Umum Syariah di Indonesia} PENDAHULUAN

Bank syariah Indonesia muncul sejak pertengahan tahun 1970. Perbankan Syariah dikenal sebagai Islamic Banking yang pada awalnya dikembangkan sebagai suatu respon dari kelompok ekonomi dan praktisi yang berlingkup syariah. Para ulama pada waktu itu berusaha untuk mendirikan bank bebas bunga, tetapi tidak ada satupun perangkat hukum yang dapat dirujuk, kecuali bahwa perbankan dapat saja menetapkan bunga sebesar $0 \%$. Bank Muamalat Indonesia adalah bank syariah pertama di Indonesia yang lahir sebelum lahirnya Undang-Undang No.7 tahun 1992. BMI lahir sebagai hasil kerja tim perbankan MUI. Akte pendirian PT Bank Muamalat Indonesia ditandatangani pada tanggal 1 November 1991. Keberadaan BMI semakin diperkuat secara konstitusi dengan munculnya Undang-Undang No.7 tahun 1992 tentang Perbankan, di mana perbankan bagi hasil tersebut di akomodasi. ${ }^{1}$ Saat krisis ekonomi tahun 1998 yang menyebabkan Presiden Soeharto lengser, para bankir sempat heran mengapa Bank Muamalat bisa bertahan dari krisis yang membuat belasan bank konvensional lain tersungkur tak berdaya. Terinspirasi dengan tegarnya Bank Muamalat menghadapi krisis, maka berdirilah Bank Syariah Mandiri, bank syariah kedua di Indonesia. ${ }^{2}$

Akhir tahun 1999, bersamaan dengan dikeluarkannya UU perbankan maka muncullah bank-bank syariah umum dan Bank umum yang membukan unit usaha syariah. Sejak beroperasinya Bank Muamalat Indonesia (BMI) sebagai Bank syariah yang pertama pada tahun 1992, data Bank Indonesia per 30 Mei 2007 menunjukkan bahwa saat ini perbankan syariah nasioanal telah tumbuh cepat, ketika pelakunya terdiri atas 3 Bank Umum Syariah (BUS), 23 Unit Usaha Syariah(UUS), dan 106 Bank Perkreditan Rakyat Syariah (BPRS). ${ }^{3}$ Selanjutnya, berdasarkan data dari Otoritas Jasa Keuangan (OJK), yaitu Statistik Perbankan Syariah (SPS) bulan Januari 2020, terdapat 14 Bank Umum Syariah (BUS), 20 Unit Usaha Syariah (UUS) dan 164 Bank Pembiayaan Rakyat Syariah (BPRS).

Bank umum adalah bank yang melaksanakan kegiatan usaha secara konvensional dan atau berdasarkan prinsip syariah, yang dalam kegiatannya memberikan jasa dalam lalu lintas pembayaran. Bank Umum Syariah (BUS) adalah bank yang melaksanakan kegiatan usaha berdasarkan prinsip syariah yang dalam kegiatannya memberikan jasa dalam lalu lintas pembayaran. BUS merupakan badan usaha yang setara dengan bank umum konvensional dengan bentuk hukum Perseroan Terbatas, Perusahaan Daerah, atau Koperasi.Seperti halnya bank umum konvensional, BUS dapat berusaha sebagaibank devisa atau bank non-devisa. ${ }^{4}$

Berdirinya bank di Indonesia memiliki dampak tersendiri baik untuk masyarakat maupun dalam bidang perbankan. Bank syariah menyalurkan dana yang diperoleh dari masyarakat dalam bentuk simpanan dan disalurkan kepada masyarakat dalam bentuk pembiayaan. Akan tetapi, pembiayaan yang diberikan tidak sepenuhnya berjalan lancar, hal ini mempengaruhi profitabilitas bank syariah. Apabila pembiayaan yang diberikan lancar maka profitabilitas akan bagus, namun sebaliknya apabila pembiayaan yang diberikan

\footnotetext{
${ }^{1}$ Nofinawati, "PERKEMBANGAN PERBANKAN SYARIAH DI INDONESIA," JURIS 14, no. 2 (Juni 2015): hlm. 171-172.

2 Alfina Sindy Pastiani, "Perkembangan Perbankan Syariah di Indonesia," Fakultas Ekonomi, Manajemen Universitas Djuanda, November 2019, hlm. 10-11.

${ }^{3}$ Agus Marimin dan Abdul Haris Romdhoni, "PERKEMBANGAN BANK SYARIAH DI INDONESIA," Jurnal Ilmiah Ekonomi Islam 1, no. 02 (10 Februari 2017): hlm. 82, https://doi.org/10.29040/jiei.v1i02.30.

${ }^{4}$ Ascarya, Bank Syariah Gambaran Umum (Jakarta: Bank Indonesia, 2005), hlm. 68.
}

SHAFIN: Finance and Sharia Accounting Journal 
mengalami macet, hal ini akan berdampak buruk terhadap profitabilitas bank tersebut. ${ }^{5}$ Adanya pembiayaan yang diberikan oleh bank kepada nasabah tidak terlepas dari adanya risiko kredit. Risiko kredit dapat ditunjukkan oleh tingkat Non Performing Finance (NPF) Bank Umum Syariah Periode 2017-2019:

Gambar 1.

Tingkat NPF Bank Umum Syariah Periode 2017-2019

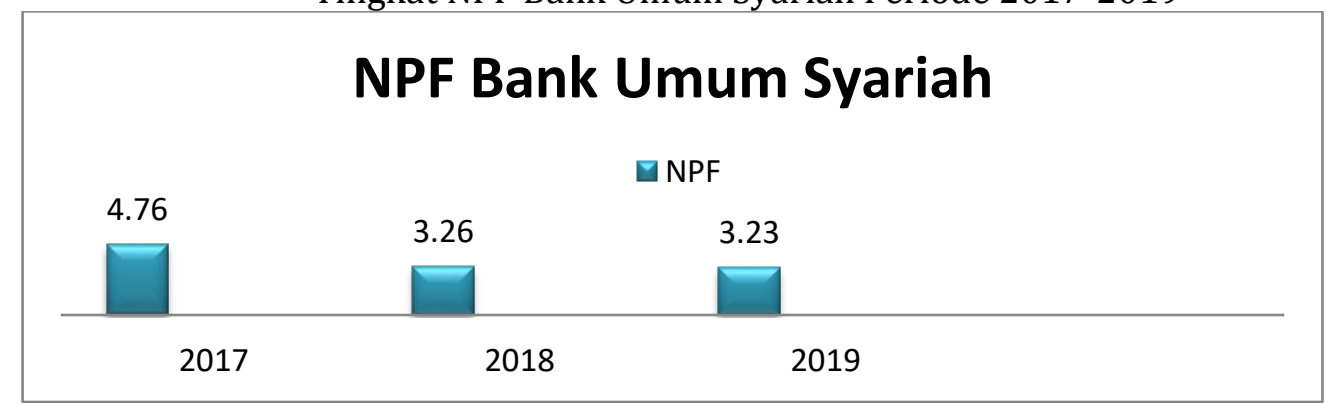

Risiko kredit yang ditunjukan oleh tingkat NPF dari tahun 2017 hingga 2019 mengalami penurunan. Pada tahun 2017, NPF cenderung meningkat dengan nilai NPF yaitu 4,76\%. Pada tahun 2018, NPF menurun dengan nilai NPF yaitu 3,26\%. Pada tahun 2019, NPF mengalami sedikit penurunan dengan nilai NPF yaitu 3,23\%. Yang menunjukkan bahwa semakin kecil rasio NPF ini maka kualitas pembiayaan semakin sehat.

Pembiayaan mudharabah adalah kerjasama antara seorang partner yang memberikan uang kepada partner lain untuk diinvestasikan kepada perusahaan komersial. Pihak (mudharib) dan mudharib hanya mengelola usaha yang sudah ditentukan oleh pihak shahibul mal. Pembagian keuntungan akan dibagi berdasarkan kesepakatan pada awal kontrak, sedangkan jika terjadi kerugian akan ditanggung oleh pemilik modal. Pembiayaan musyarakah adalah kerjasama dimana dua atau lebih pengusaha bekerja sama sebagai mitra usaha dalam bisnis. Masing-masing pihak menyertakan modalnnya dan ikut mengelolah usaha tersebut. keuntungan dan kerugian akan dibagi berdasarkan presentase penyertaan modalnya. ${ }^{6}$ Bank Umum Syariah dalam mempertahankan sekaligus meningkatkan profitabilitas melalui berbagai hal salah satunya memberikan pembiayaan secara hati-hati dan sehat. Berikut adalah data perkembangan pembiayaan Bank Umum Syariah:

Tabel 1.

Perkembangan Pembiayaan Bank Umum Syariah

\begin{tabular}{llcc} 
& & & (Miliar Rupiah) \\
\hline Akad & 2017 & 2018 & 2019 \\
\hline Mudharabah & 6.584 & 5.477 & 5.413 \\
Musyarakah & 60.465 & 68.644 & 84.582 \\
Total & 67.049 & 74.121 & 89.995 \\
\hline
\end{tabular}

\footnotetext{
5 Yulius Dharma dan Ade Pristianda, "PENGARUH PEMBIAYAAN MUDHARABAH DAN MURABAHAH TERHADAP PROFITABILITAS (RETURN ON ASSETS) BANK PEMBIAYAAN RAKYAT SYARIAH DI INDONESIA 2012-2016," Jurnal Ekonomika Indonesia VII, no. 02 (Desember 2015): hlm. 60-61.

${ }^{6}$ Russely Inti Dwi Permata, Fransisca Yaningwati, dan Zahroh Z.A, "ANALISIS PENGARUH PEMBIAYAAN MUDHARABAH DAN MUSYARAKAH TERHADAP TINGKAT PROFITABILITAS (RETURN ON EQUITY)," Jurnal Administrasi Bisnis (JAB) 12, no. 1 (Juli 2014): hlm. 3-4.
} 
Praktik Pembiayaan Mudharabah dan Musyarakah terhadap Profitabilitas Bank Umum Syariah di Indonesia

Berdasarkan perkembangan pembiayaan Bank Umum Syariah diatas, pembiayaan mudharabah dari tahun 2017-2019 mengalami penurunan. Sedangkan pada pembiayaan musyarakah dari tahun 2017-2019 mengalami kenaikan yang drastis.

Dalam suatu bank pastinya terdapat rasio profitabilitas yang dapat didefinisikan sebagai kemampuan perusahaan dalam menghasilkan laba selama periode tertentu yang dapat dipakai sebagai alat mengukur hasil operasi perusahaan, profitabilitas dapat dijadikan gambaran dari kinerja manajemen dilihat dari keuntungan yang diperoleh. Dalam industri perbankan profitabilitas diartikan bagaimana cara bank memaksimalkan profit dengan dana yang dimiliki.7 Dalam penelitian ini perhitungan profitabilitas menggunakan sebuah akad pengukuran yang disebut ROA (Return on Asset). Menurut Hanafi (2016:157) ROA mengukur kemampuan perusahaan menghasilkan laba dengan menggunakan total aset (kekayaan) yang dipunyai oleh perusahaan setelah disesuaikan dengan biaya-biaya untuk mendanai aset tersebut. ${ }^{8}$ Berikut data perkembangan ROA (Return On Asset) pada Bank Umum Syariah:

Tabel 2.

Perkembangan ROA BRI Syariah

\begin{tabular}{llll}
\hline RASIO & 2017 & 2018 & 2019 \\
\hline Return On Assets (ROA) & $0,63 \%$ & $1,28 \%$ & $1,73 \%$ \\
\hline
\end{tabular}

Jika dilihat dari data diatas, ROA dari tahun 2017 hingga tahun 2019 mengalami peningkatan, yakni dari $0,63 \%$ pada tahun $2017,1,28 \%$ pada tahun $2018,1,73 \%$ pada tahun 2019. Sehingga peneliti disini akan meneliti apakah terdapat pengaruh antara pembiayaan mudharabah dan pembiayaan musyarakah terhadap profitabilitas Bank Umum Syariah pada periode 2017-2019.

Pembiayaan musyarakah dan mudharabah dalam jumlah besar dapat membawa hasil yang menguntungkan bagi pihak bank, jika penyaluran pembiayaan tersebut dalam pengembaliannya berjalan dengan lancar. Dengan begitu profitabilitas menjadi faktor penting dalam penilaian aktivitas perbankan syariah dalam kegiatannya. Besarnya laba atau profit tentu berhubungan dengan besarnya pembiayaan yang disalurkan serta menunjukkan tingkat keberhasilan bank syariah dalam melakukan kegiatan usahanya. ${ }^{9}$

Adapun tentang pembiayaan mudharabah, musyarakah dan profitabilitas sudah pernah dilakukan sebelumnya oleh beberapa peneliti, antara lain: Penelitian yang dilakukan oleh Felani (2017) yang berjudul "Pengaruh Pendapatan Mudharabah, Musyarakah dan Murabahah Terhadap Profitabilitas (ROA)" bahwa pembiayaan mudharabah secara parsial berpengaruh negatif terhadap ROA. Pembiayaan musyarakah mempunyai pengaruh yang positif terhadap ROA. Dan pembiayaan murabahah mempunyai pengaruh yang negatif terhadap ROA.10 Namun, menurut Romdhoni dan Yozika (2018) dalam penelitian Pengaruh

\footnotetext{
${ }^{7}$ Muhammad Iqbal Notoatmojo, "ANALISIS DAMPAK LIKUIDITAS TERHADAP PROFITABILITAS PADA BANK UMUM SYARIAH DI INDONESIA PERIODE 2010 -2016," Equilibrium: Jurnal Ekonomi Syariah 6, no. 1 (29 Juli 2018): hlm. 25-26, https://doi.org/10.21043/equilibrium.v6i1.3254.

8 Anisya Dwi Fazriani dan Rimi Gusliana Mais, "Pengaruh Pembiayaan Mudharabah, Musyarakah, dan Murabahah terhadap Return On Asset melalui Non Performing Financing sebagai Variabel Intervening (pada Bank Umum Syariah yang Terdaftar diotoritas Jasa Keuangan)," Jurnal Akuntansi dan Manajemen 16, no. 01 (8 April 2019): hlm. 6-7, https://doi.org/10.36406/jam.v16i01.265.

${ }^{9}$ Aditya Refinaldy, Septarina Prita Dania Sofianti, dan Yosefa Sayekti, "Pengaruh Tingkat Pembiayaan Musyarakah Dan Pembiayaan Mudharabah Terhadap Tingkat Profitabilitas Bank Syariah," Jurusan Akuntansi, Fakultas Ekonomi, Universitas Jember, t.t., hlm. 128.

10 Fazriani dan Mais, "Pengaruh Pembiayaan Mudharabah, Musyarakah, dan Murabahah terhadap Return On Asset melalui Non Performing Financing sebagai Variabel Intervening (pada Bank Umum Syariah yang Terdaftar diotoritas Jasa Keuangan)," hlm. 4.
}

SHAFIN: Finance and Sharia Accounting Journal

Vol. 1 No. 1 Maret 2021 
Pembiayaan Mudharabah, Musyarakah dan Ijarah terhadap Profitabilitas. Hasil dari penelitian ini adalah pembiayaan mudharabah secara statistik tidak berpengaruh terhadap profitabilitas (ROA). Kemudian ijarah secara statistik tidak berpengaruh terhadap profitabilitas (ROA). Sedangkan pembiayaan musyarakah secara statistik berpengaruh negatif terhadap profitabilitas (ROA). Dan pembiayaan mudharabah, musyarakah secara bersamasama berpengaruh terhadap profitabilitas (ROA). ${ }^{11}$

Berdasarkan pemaparan fenomena dan adanya gap hasil penelitian di atas, peneliti tertarik untuk melanjutkan penelitian yang sama dengan menggunakan objek dan periode yang berbeda dengan judul "Praktik Pembiayaan Mudharabah dan Musyarakah terhadap Profitabilitas Bank Umum Syariah di Indonesia (Periode 2017-2019)".

$\mathrm{H}_{1} \quad$ : pembiayaan mudharabah berpengaruh signifikan terhadap ROA bank umum syariah secara parsial.

$\mathrm{H}_{2}$ : pembiayaan musyarakah berpengaruh signifikan terhadap ROA bank umum syariah secara parsial.

$\mathrm{H}_{3}$ : pembiayaan mudharabah dan musyarakah berpengaruh signifikan terhadap ROA bank umum syariah secara simultan,

\section{METODE PENELITIAN}

Penelitian ini menggunakan pendekatan kuantitatif dengan jenis penelitian yang digunakan adalah penelitian asosiatif. Variabel yang digunakan dalam penelitian ini terdiri dari 2 variabel independent, yaitu: pembiayaan mudharabah dengan indikator penelitian berupa jumlah pembiayaan mudharabah dengan skala pengukurannya adalah skala rasio; pembiayaan musyarakah dengan indikator penelitian berupa jumlah pembiayaan musyarakah, dan skala pengukurannya adalah skala rasio. Serta variabel dependent, yaitu tingkat ROA dengan indikator penelitian yang digunakan adalah laba sebelum pajak dan total asset, dan skala pengukurannya adalah skala rasio.

Sumber data yang digunakan adalah data sekunder yang merupakan data runtut waktu (time series) dan cross section, yang diperoleh dari laporan publikasi Bank Umum Syariah yang dipublikasi di website resmi Otoritas Jasa Keuangan (OJK) yaitu www.ojk.go.id. Populasi yang digunakan dalam penelitian ini yaitu seluruh Bank Umum Syariah (BUS) yang terdaftar di Bank Indonesia (BI). Teknik pengambilan sampel yaitu dengan menggunakan teknik Simple Random Sample. Teknik pengumpulan data menggunakan teknik dokumentasi berupa data laporan keuangan triwulan Bank Umum Syariah dari website resmi Otoritas Jasa Keuangan.

Teknik analisis data yang digunakan adalah Uji asumsi klasik (uji normalitas, uji autokorelasi, uji heteroskedastisitas, uji multikolinearitas), uji analisis persamaan regresi linear berganda, dan uji statistik (uji $t$, uji $F$ dan uji koefisien determinasi)dengan menggunakan aplikasi spss.

\section{HASIL DAN PEMBAHASAN \\ Uji Normalitas}

Uji Normalitas bertujuan untuk mengetahui apakah nilai residual berdistribusi normal atau tidak. Model regresi yang baik adalah memiliki nilai residual yang berdistribusi

\footnotetext{
${ }^{11}$ Fazriani dan Mais, hlm. 11.
} 
Praktik Pembiayaan Mudharabah dan Musyarakah terhadap Profitabilitas Bank Umum Syariah di Indonesia normal. Salah satu cara untuk melihat normalitas adalah secara visual yaitu melalui Normal P-Plot (normal probability plot), ketentuannya adalah jika titik-titik masih berada disekitar garis diagonal maka dapat dikatakan bahwa residual menyebar normal. Adapun Normal PPlot dalam penelitian ini dapat dilihat pada gambar dibawah ini:

Gambar 2.

Hasil Uji Normalitas

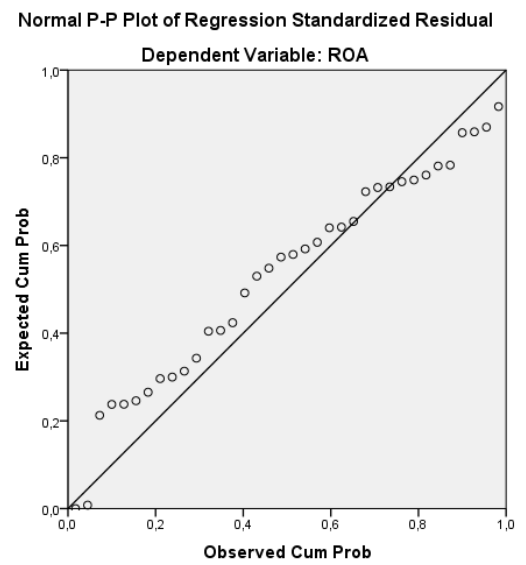

Berdasarkan grafik P-Plot diatas, menunjukkan bahwa data ploting (titik-titik) mengikuti garis diagonal dan menyebar berhimpit disekitar diagonal yang menunjukkan bahwa model regresi ini berdistribusi normal. Namun pengujian secara visual ini cenderung kurang valid, sehingga dilakukan Uji Kolmogrov-Smirov (K-S). Uji Kolmogrov-Smirnov merupakan bagian dari uji asumsi klasik. Adapun dasar pengambilan keputusannya adalah:

1) Jika nilai signifikansi $>0,05$, maka nilai residual berdistribusi normal

2) Jika nilai signifikansi $<0,05$, maka nilai residual tidak berdistribusi normal

Adapun hasil perhitungan uji normalitas dengan uji Kolmogrv-Smirnov adalah sebagai berikut:

Tabel 3.

Hasil Uji Normalitas One-Sample Kolmogrov-Smirnov Test

\begin{tabular}{lcc}
\hline & & \multicolumn{2}{c}{$\begin{array}{c}\text { Unstandardized } \\
\text { Residual }\end{array}$} \\
\hline $\mathrm{N}$ & Mean & 36 \\
Normal Parameters $^{\text {a.b }}$ &, 0000000 \\
& Std. Deviation &, 51581925 \\
Most Extreme Differences Absolute &, 134 \\
& Positive &, 134 \\
Test Statistic & Negative &,- 095 \\
Asymp. Sig. (2-tailed) & &, 134 \\
& &, $103^{c}$
\end{tabular}

a. Test distribution is Normal

b. Calculated from data

c. Lilliefors Significance Correction 
Berdasarkan output hasil perhitungan uji normalitas diatas, dapat diketahui bahwa nilai Asymp. Sig. (2-tailed) sebesar 0,103. Yang menunjukkan bahwa nilai 0,103 lebih besar dari 0,05 sehingga dapat disimpulkan bahwa data dalam penelitian ini berdistribusi normal.

\section{Uji Autokorelasi}

Uji autokorelasi bertujuan untuk menguji apakah dalam model regresi terdapat korelasi antara kesalahan pengganggu pada periode $t$ dengan kesalahan pada periode $t 1$ (sebelumnya). Uji autokorelasi ini dilakukan dengan mengunakan pendekatan DurbinWatson. Dengan dasar pengambilan keputusan yaitu nilai Durbin-Watson terletak antara $\mathrm{d}_{\mathrm{u}}$ dengan 4- $\mathrm{d}_{\mathrm{u}}$. Dibawah ini adalah hasil uji autokorelasi dengan pendekatan Durbin-Watson.

Tabel 4.

Hasil Uji Autokorelasi Model Summaryb

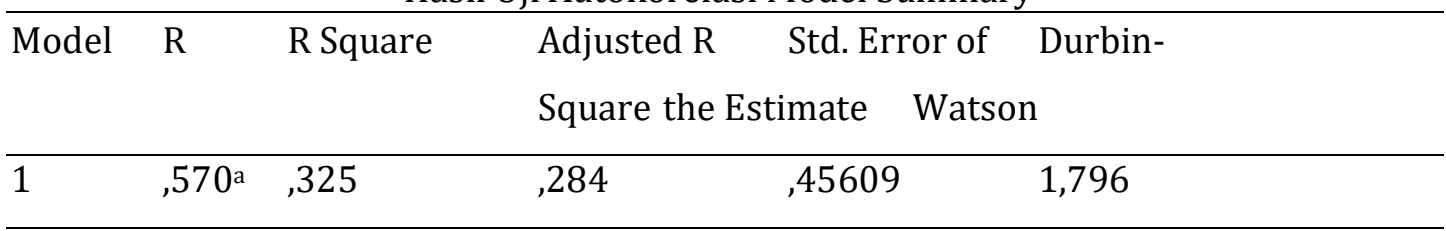

a. Predictors: (Constant), PembiayaanMusyarakah, PembiayaanMudharabah

b. Dependent Variable: ROA

Berdasarkan output hasil perhitungan uji autokorelasi dengan pendekatan Durbin Watson, diperoleh nilai Durbin Watson sebesar 1,796. Nilai 1,796 ini terletak diantara nilai $d_{u}$ sebesar 1,587 dan nilai 4- $\mathrm{d}_{\mathrm{u}}$ sebesar 2,413. Sehingga dapat disimpulkan bahwa dalam model regresi tidak terdapat gejala autokorelasi.

\section{Uji Heteroskedastisitas}

Uji heteroskedastisitas bertujuan untuk mengetahui ada tidaknya kesamaan varian dari nilai residual untuk semua pengamatan pada model regresi. Heterskedastisitas merupakan salah satu faktor yang menyebabkan model regresi linear tidak efisien dan akurat. Model regresi yang baik ditandai dengan tidak terjadi gejala heteroskedastisitas.

Gambar 3.

Hasil Uji Heterokedasitas

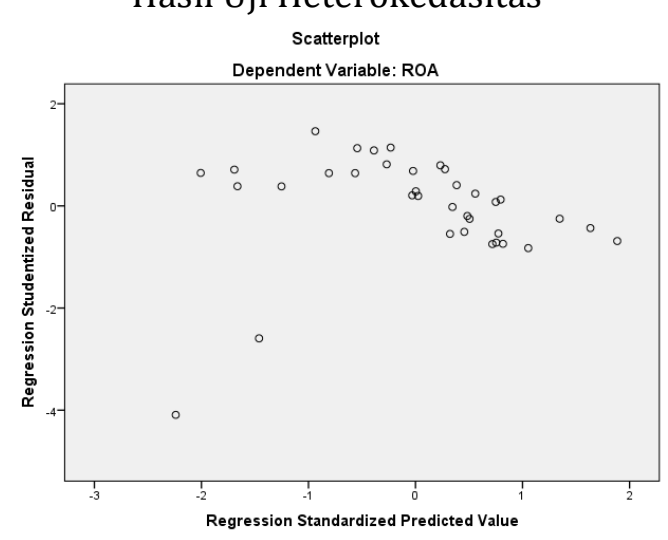


Berdasarkan gambar Scatterplot diatas, terlihat bahwa titik-titik menyebar diatas dan dibawah angka 0 pada sumbu Y. Sehingga, dapat disimpulkan bahwa dalam model regresi tidak terdapat masalah heteroskedastisitas.

\section{Uji Multikolinearitas}

Uji multikolinearitas bertujuan untuk mengetahui apakah terjadi interkorelasi (hubungan yang kuat) antar variabel independent. Model regresi yang baik ditandai dengan tidak terjadi interkorelasi antar variabel independent, yaitu pembiayaan mudharabah dan pembiayaan musyarakah. Salah satu cara yang paling akurat untuk mendeteksi ada atau tidaknya gejala multikolinearitas ini yaitu dengan menggunakan metode Tolerance dan VIF (Variance Inflation Factor).

Tabel 5.

Hasil Uji Multikolinearitas

Coefficients $^{\mathrm{a}}$

\begin{tabular}{llcl}
\hline Model & & \multicolumn{2}{c}{ Collinearity } \\
& & Statistics \\
& & Tolerance & VIF \\
\hline \multirow{2}{*}{1} & PembiayaanMudharabah &, 599 & 1,669 \\
& PembiayaanMusyarakah &, 599 & 1,669 \\
\hline
\end{tabular}

a. Dependent Variable: ROA

Berdasarkan output hasil perhitungan uji multikolinearitas diatas, terlihat bahwa nilai Tolerance pembiayaan mudharabah sebesar 0,599 dan pembiayaan musyarakah sebesar 0,599 , yang menunjukkan bahwa nilai 0,599 > 0,10 sehingga dapat disimpulkan bahwa tidak terjadi gejala pada variabel independent. Nilai VIF pada pembiayaan mudharabah sebesar 1,699 dan pembiayaan musyarakah sebesar 1,699, yang menunjukkan bahwa nilai 1,699< 10,00 sehingga dapat disimpulkan bahwa model regresi terbebas dari gejala multikolinearitas antar variabel independent.

Berdasarkan teknik analisis data dengan uji asumsi klasik yang menyatakan bahwa data dalam penelitian ini berdistribusi normal, tidak terjadi gejala autokorelasi, heteroskedastisitas dan multikolinearitas. Maka, analisis dapat dilanjutkan dengan uji analisis regresi linear berganda untuk pengujian hipotesis.

\section{Uji Analisis Persamaan Regresi Linear Berganda}

Analisis regresi linear berganda digunakan untuk mengetahui arah hubungan antara variabel independent (variabel bebas) dengan variabel dependent (variabel terikat) apakah berhubungan positif atau negatif serta untuk meramalkan bagaimana keadaan (naik turunnya) variabel dependent jika variabel independent mengalami kenaikan atau penurunan.

Tabel 6.

Analisis Regresi Berganda

Coefficients $^{\mathrm{a}}$

\begin{tabular}{|c|c|c|c|c|c|c|}
\hline \multirow{2}{*}{\multicolumn{2}{|c|}{ Model }} & \multicolumn{2}{|c|}{$\begin{array}{c}\text { Unstandardized } \\
\text { Coefficients }\end{array}$} & \multirow{2}{*}{$\begin{array}{c}\text { Standardize } \\
d \\
\text { Coefficients } \\
\text { Beta } \\
\end{array}$} & \multirow{2}{*}{$\mathrm{t}$} & \multirow{2}{*}{ Sig. } \\
\hline & & B & Std. Error & & & \\
\hline \multirow[t]{3}{*}{1} & Constant & 2,818 & 3,856 & & 731 & ,470 \\
\hline & Pemb. & 1,184 & ,325 & 673 & 3,643 & 001 \\
\hline & Mudharabah & $-1,333$ & ,374 &,- 658 & $-3,562$ & ,001 \\
\hline
\end{tabular}

SHAFIN: Finance and Sharia Accounting Journal 
Pemb.

Musyarakah

a. Dependent Variable: ROA

Berdasarkan pada output Coefficients diatas, maka untuk memperoleh persamaan regresinya maka perlu memperhatikan output Coefficients pada bagian Unstandardized Coefficients B, yaitu pada baris pertama menunjukkan nilai konstanta (a) dan baris berikutnya menunjukkan nilai koefisien dari variabel independent $\left(b_{1}\right.$ dan $b_{2}$ ). Berdasarkan tabel dan penjelasan tersebut maka persamaan regresi berganda adalah sebagai berikut:

$\mathrm{Y}=\mathrm{a}+\mathrm{b}_{1} \mathrm{X}_{1}+\mathrm{b}_{2} \mathrm{X}_{2}$

$\mathrm{Y}=2,818+1,184$ Pembiayaan Mudharabah - 1,333 Pembiayaan Musyarakah

Jadi, nilai konstanta (a) sebesar 2,818 yang menunjukkan bahwa pembiayaan mudharabah dan pembiayaan musyarakah sebagai variabel independent adalah konstan atau tetap, sehingga rata-rata ROA akan tetap sebesar 2,818. Koefisien regresi variabel pembiayaan mudharabah $\left(\mathrm{b}_{1}\right)$ bernilai positif yaitu sebesar 1,184 yang berarti setiap kenaikan satu satuan pembiayaan mudharabah maka tingkat ROA akan meningkat sebesar 1,184 satuan. Pada Koefisien regresi variabel pembiayaan musyarakah $\left(\mathrm{b}_{2}\right)$ bernilai negatif yaitu sebesar $-1,333$ yang berarti setiap kenaikan satu satuan pembiayaan musyarakah maka tingkat ROA akan menurun sebesar 1,333 satuan.

\section{Uji t (Parsial)}

Uji t (parsial) ini digunakan untuk menguji apakah terdapat pengaruh antara variabel independen terhadap variabel dependen secara parsial atau individu. Pengujian ini dapat dilakukan dengan membandingkan nilai $t_{\text {hitung }}$ dan $t_{\text {tabel. }}$. Apabila nilai $t_{h i t u n g}>$ nilai $t_{\text {tabel, }}$ maka variabel independen berpengaruh terhadap variabel dependen secara parsial. Sebaliknya, jika nilai $t_{\text {hitung }}<$ nilai $t_{\text {tabel, }}$, maka variabel independen tidak berpengaruh terhadap variabel dependen secara parsial.

Tabel 7.

Hasil Uji Statistik t (Parsial)

\begin{tabular}{|c|c|c|c|c|c|c|}
\hline \multirow{2}{*}{\multicolumn{2}{|c|}{ Model }} & \multicolumn{2}{|c|}{$\begin{array}{l}\text { Unstandardized } \\
\text { Coefficients }\end{array}$} & \multirow{2}{*}{$\begin{array}{c}\begin{array}{c}\text { Standardize } \\
\mathrm{d} \\
\text { Coefficients }\end{array} \\
\text { Beta }\end{array}$} & \multirow{2}{*}{$\mathrm{t}$} & \multirow{2}{*}{ Sig. } \\
\hline & & B & $\begin{array}{l}\text { Std. } \\
\text { Error }\end{array}$ & & & \\
\hline \multirow[t]{3}{*}{1} & Constant & 2,818 & 3,856 & & ,731 & ,470 \\
\hline & Pemb. & 1,184 & ,325 & 673 & 3,643 & 001 \\
\hline & $\begin{array}{l}\text { Mudharabah } \\
\text { Pemb. } \\
\text { Musyarakah }\end{array}$ & $-1,333$ & 374 &,- 658 & $-3,562$ & 001 \\
\hline
\end{tabular}

a. Dependent Variable: ROA

Berdasarkan pada tabel output Coefficients diatas, hasil yang diperoleh untuk nilai $t_{\text {tabel }}$ sebesar 2,035 dengan taraf signifikansi $(\alpha=5 \%)$. Maka hasil uji t statistik adalah sebagai berikut:

1) Hasil pengujian pada variabel pembiayaan mudharabah diperoleh nilai $t_{\text {hitung }}$ sebesar 3,643 $>t_{\text {tabel }}$ sebesar 2,035 dan nilai signifikansi sebesar 0,001 $<0,05$. Hal tersebut membuktikan 
Praktik Pembiayaan Mudharabah dan Musyarakah terhadap Profitabilitas Bank Umum Syariah di Indonesia bahwa $\mathrm{H}_{1}$ diterima, sehingga pembiayaan mudharabah memberikan pengaruh yang signifikan terhadap tingkat profitabilitas (ROA) Bank Umum Syariah.

2) Hasil pengujian pada variabel pembiayaan musyarakah diperoleh nilai $t_{\text {hitung }}$ sebesar 3,562 $>t_{\text {tabel }}$ sebesar 2,035 dan nilai signifikansi sebesar 0,001 $<0,05$. Hal tersebut juga membuktikan bahwa $\mathrm{H}_{2}$ diterima, sehingga pembiayaan musyarakah memberikan pengaruh yang signifikan terhadap tingkat profitabilitas (ROA) Bank Umum Syariah.

\section{Uji F (Simultan)}

Uji F (Simultan) digunakan untuk menguji apakah variabel independen yaitu pembiayaan mudharabah dan pembiayaan musyarakah secara simultan berpengaruh terhadap variabel dependen yaitu ROA. Pengujian ini dapat dilakukan dengan cara membandingkan nilai $\mathrm{f}_{\text {hitung }}$ dengan nilai $\mathrm{f}_{\text {tabel. }}$.

Tabel 8.

Hasil Uji Statistik F (Simultan)

ANOVA $^{\mathrm{a}}$

\begin{tabular}{llcrlll}
\hline Model & & Sum of & Mean & & & \\
& & Squares & df & Square & F & Sig. \\
\hline $\mathbf{1}$ & Regression & 3,308 & 2 & 1,654 & 7,952 &, $002^{\mathrm{b}}$ \\
& Residual & 6,865 & 33 &, 208 & & \\
& Total & 10,173 & 35 & & & \\
& Total & &
\end{tabular}

a. Dependent Variable: ROA

b. Predictors: (Constant), PembiayaanMusyarakah, PembiayaanMudharabah

Berdasarkan pada output tabel ANOVA diatas, diperoleh nilai $\mathrm{f}_{\text {hitung }}$ sebesar 7,952 dan nilai $f_{\text {tabel }}$ sebesar 3,28 serta nilai signifikansi yaitu 0,002. Yang berarti bahwa nilai $f_{\text {hitung }}>f_{\text {tabel }}$ dan nilai Sig $(0,002)<0,05$, sehingga $\mathrm{H}_{3}$ diterima. Maka dapat ditarik kesimpulan bahwa terdapat pengaruh yang signifikan antara pembiayaan mudharabah dan pembiayaan musyarakah terhadap tingkat profitabilitas (ROA) Bank Umum Syariah secara simultan.

\section{Uji Koefisien Determinasi}

Koefisien Determinasi $\left(\mathrm{R}^{2}\right)$ pada intinya mengukur seberapa jauh kemampuan model menerangkan variasi variabel independen. Nilai koefisien determinasi adalah antara nol dan satu. Nilai $\mathrm{R}^{2}$ yang kecil berarti kemampuan variabel-variabel independen dalam menjelaskan variasi variabel dependen sangat terbatas. Nilai yang mendekati satu berarti variabelvariabel independen memberikan hampir semua informasi yang dibutuhkan untuk memprediksi variasi variabel dependen.

Tabel 9.

Hasil Uji Koefisien Determinasi Model Summary ${ }^{b}$

\begin{tabular}{llllc}
\hline Model & $\mathrm{R}$ & R Square & $\begin{array}{l}\text { Adjusted R } \\
\text { Square }\end{array}$ & $\begin{array}{c}\text { Std. Error of } \\
\text { the Estimate }\end{array}$ \\
\hline 1 &, $570^{\text {a }}$ &, 325 &, 284 &, 45609
\end{tabular}

Berdasarkan output hasil perhitungan pada tabel diatas, dapat dijelaskan bahwa nilai Adjusted $\mathrm{R}$ adalah sebesar 0,284. Sehingga dapat dijelaskan bahwa 28,4\% tingkat profitiabilitas (ROA) dapat dijelaskan oleh variabel pembiayaan mudharabah dan 
pembiayaan musyarakah. Sedangkan sisanya yaitu sebesar $71,6 \%$ dijelaskan oleh faktorfaktor lain yang tidak dimasukkan dalam model regresi pada penelitian ini.

Berdasarkan hasil analisis regeresi yang telah dilakukan pada pengaruh pembiayaan mudharabah, diperoleh hasil dengan nilai signifikansi 0,001 lebih kecil dari 0,05 yang berarti bahwa pembiayaan mudharabah memberikan pengaruh yang signifikan terhadap tingkat profitabilitas (ROA). Pengaruh ini dapat dilihat dari besarnya pemberian modal oleh pihak bank syariah kepada nasabah, yang akan menentukan besarnya keuntungan dari usaha yang dibiayai tersebut. Dalam analisis hasil uji t (parsial), pembiayaan mudharabah memiliki nilai

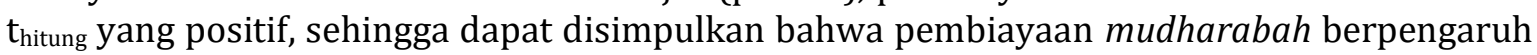
signifikan dan positif terhadap tingkat profitabilitas (ROA). Artinya bahwa semakin tinggi penyaluran pembiayaan mudharabah maka akan menambah tingkat profitabilitas (ROA) suatu bank.

Secara bahasa mudharabah diambil dari kata al-dharb fi al-Ardh, yang berarti perjalanan untuk berniaga. Pengambilan kata ini disebabkan amil dan mudharib meletakan mudharabah untuk bekerja dengan cara berniaga (tijarah) dan mencari keuntungan dengan permintaan dari pemilik modal ( $r a b$ al-mal). Secara istilah, mudharabah berarti seorang pemilik modal menyerahkan modal kepada seorang amil untuk berniaga dengan modal tersebut, dimana keuntungan dibagi diantara keduanya dengan porsi bagian sesuai dengan yang dipersyaratkan dalam akad. ${ }^{12}$

Pernyataan Standar Akuntansi Keuangan (PSAK) No.105 mendefinisikan mudharabah merupakan akad kerjasama usaha antara dua pihak dimana pihak pertama (pemilik dana) menyediakan seluruh dana, sedangkan pihak kedua (pengelola dana) bertindak selaku pengelola dan keuntungan usaha dibagi diantara mereka sesuai kesepakatan dan kerugian finansial hanya ditanggung oleh pengelola dana. ${ }^{13}$

Mudharabah adalah akad kerja sama antara dua pihak, yaitu pertama menyediakan seluruh modal dan pihak kedua nya menjadi pengelola. Keuntungan di bagi menurut kesepakatan yang di tuangkan dalam kontrak. Apabila rugi, kerugian tersebut ditanggung pemilik modal selama kerugian itu bukan akibat dari kelalaian pengelola. Apabila kerugian di akibatkan kelalaian pengelola, pengelolalah yang bertanggung jawab.

Ada dua macam al-mudharabah, yaitu:

1. Mudharabah mutlaqah merupakan kerja sama antara pihak pertama dan pihak kedua yang cakupannya lebih luas. Maksudnya, tidak di batasi oleh waktu, spesifikasi usaha, dan daerah bisnis.

2. Mudharabah muqayyadah merupakan kebalikan dari mudharabah mutlaqah, yaitu dibatasi oleh waktu spesifikasi usaha dan daerah bisnis.

Dalam dunia perbankan, al-mudharabah biasanya diaplikasikan pada produk pembiayaan atau pendanaan seperti pembiayaan modal kerja. Dana untuk kegiatan mudharabah diambil dari simpanan tabungan berjangka, seperti tabungan haji atau tabungan

\footnotetext{
${ }^{12}$ Chefi Abdul Latif, "PEMBIAYAAN MUDHARABAH DAN PEMBIAYAAN MUSYARAKAH DI PERBANKAN SYARIAH," Jurnal Ilmu Akuntansi dan Bisnis Syariah 2, no. 01 (Januari 2020): hlm. 11.

13 Deasy Rahmi Puteri, Inten Meutia, dan Emylia Yuniartie, "PENGARUH PEMBIAYAAN MUDHARABAH,MUSYARAKAH, MURABAHAH, ISTISHNA DAN IJARAH TERHADAP PROFITABILITAS PADA BANK UMUM SYARIAH DI INDONESIA," Jurnal Penelitian dan Pengembangan Akuntansi 8, no. 1 (Januari 2014): hlm. 6.

26
}

SHAFIN: Finance and Sharia Accounting Journal

Vol. 1 No. 1 Maret 2021 
Praktik Pembiayaan Mudharabah dan Musyarakah terhadap Profitabilitas Bank Umum Syariah di Indonesia kurban. Dana juga dapat dilakukan dari deposito biasa dan deposito spesial yang dititipkan nasabah untuk usaha tertentu. ${ }^{14}$

Syarat akad pembiayaan mudharabah ini adalah (1) Modal harus berupa uang atau barang yang dinilai, diketahui jumlahnya, harus tunai atau bukan piutang. (2) Keuntungan harus dibagi kedua pihak, besar keuntungan disepakati pada waktu awal kontrak, penyedia dana menanggung kerugian. Rukun akad pembiayaan adalah (1) Pelaku akad, (2) Objek akad, (3) Ijab dan qabul.Teknis pembiayaan mudharabah pada perbankan Indonesia adalah pembiayaan ditujukan untuk membiayai investasi, modal kerja dan penyediaan fasilitas. Penghitungan bagi hasil menggunakan metode revenue sharing, dikarenakan resiko yang ditanggung lebih kecil kerugiannya. Pendapatan pemiliki modal bergantung pada ketidakpastian usaha dan biaya-biaya yang ditimbulkan dalam proses tersebut. ${ }^{15}$.Berdasarkan teori tersebut, dapat diketahui bahwa semakin tinggi proporsi penyaluran pembiayaan mudharabah yang disalurkan kepada nasabah dan pengembaliannya pun lancar, maka semakin tinggi pula tingkat profitabilitas (ROA) suatu bank.

Berdasarkan hasil analisis regeresi yang telah dilakukan pada pengaruh pembiayaan musyarakah, diperoleh hasil dengan nilai signifikansi 0,001 lebih kecil dari 0,05 yang berarti bahwa pembiayaan musyarakah memberikan pengaruh yang signifikan terhadap tingkat profitabilitas (ROA). Pengaruh ini dapat dilihat dari besarnya pemberian kontribusi dana oleh pihak bank syariah kepada nasabah untuk melakukan suatu usaha tertentu, yang nantinya keuntungan ataupun risiko akan ditanggung bersama sesuai dengan kesepakatan. Dalam analisis hasil uji $\mathrm{t}$ (parsial), pembiayaan musyarakah memiliki nilai thitung yang negatif, sehingga dapat disimpulkan bahwa pembiayaan musyarakah berpengaruh signifikan dan negatif terhadap tingkat profitabilitas (ROA). Artinya bahwa semakin tinggi kontribusi dana pada pembiayaan musyarakah maka akan menurunkan tingkat profitabilitas (ROA) suatu bank.

Secara bahasa musyarakah sering pula disebut dengan syirkah yang bermakna ihktilath (pencampuran), yakni bercampurnya salah satu dari dua harta dengan harta lainnya tanpa dapat dibedakan diantara keduanya. Musyarakah juga bisa berarti seseorang mencampur hartanya dengan harta orang lain dengan mana salah satu pihak tidak menceraikan dari yang lainnya. Secara terminologi, musyarakah berarti akad diantara dua orang atau lebih untuk berserikat dalam modal dan keuntungan. ${ }^{16}$

IAI dalam PSAK 106 mendefinisikan musyarakah sebagai akad kerja sama antara dua pihak atau lebih untuk suatu usaha tertentu dengan kondisi masing-masing pihak memberikan kontribusi dana, dengan ketentuan bahwa keuntungan dibagi berdasarkan kesepakatan, sedangkan kerugian berdasarkan porsi kontribusi dana. ${ }^{17}$ Al-musyarakah adalah akad kerja sama antara dua pihak atau lebih untuk melakukan usaha tertentu. Masingmasing pihak memberikan dana atau amal dengan kesepakatan bahwa keuntungan atau risiko akan di tanggung bersama sesuai dengan kesepakatan. Al-musyarakah dalam praktik perbankan diaplikasikan dalam hal pembiayaan proyek. Dalam hal ini nasabah yang dibiayai dengan bank sama-sama menyediakan dana untuk melaksanakan proyek tersebut. Keuntungan dari proyek di bagi sesuai dengan kesepakatan untuk bank setelah

\footnotetext{
${ }^{14}$ Khaerul Umam, Manajemen Perbankan Syariah (Bandung: Pustaka Setia, 2013), hlm. 33.

15 Permata, Yaningwati, dan Z.A, "ANALISIS PENGARUH PEMBIAYAAN MUDHARABAH DAN MUSYARAKAH TERHADAP TINGKAT PROFITABILITAS (RETURN ON EQUITY)," hlm. 3-4.

${ }^{16}$ Latif, "PEMBIAYAAN MUDHARABAH DAN PEMBIAYAAN MUSYARAKAH DI PERBANKAN SYARIAH," hlm. 14.

${ }^{17}$ Rizal Yaya, Aji Erlangga Martawireja, dan Ahim Abdurahim, Akuntansi Perbankan Syariah Teori dan Praktik Kontemporer Berdasarkan PAPSI 2013, Edisi 2 (Jakarta: Salemba Empat, 2014), hlm. 142.
} 
mengembalikan dana yang dipakai nasabah. Al-musyarakah dapat pula di lakukan untuk kegiatan investasi seperti di lembaga keuangan modal ventura. ${ }^{18}$

Syarat akad Musyarakah adalah (1) Berlakunya akad, (2) Sahnya akad, (3) Terealisasinya akad, (4) Syarat lazim. Rukun akad Musyarakah adalah (1) Pelaku akad, (2) Objek akad, (3) Ijab dan qabul.

Jenis pembiayaan musyarakah adalah (1) Syirkah al-milk, kepemilikan dua atau lebih pihak dari suatu property, (2) Syirkah al-'aqd, kemitraan terjadi karena kontrak bersama. Syirkah al-aqd'ini dibagi menjadi empat, yaitu: (1) Syirkah al-amwal, kerjasama antar mitra usaha dimana porsi penyertaan modal dan kerja tidak sama, (2) Syirkah al-mufawadhah, kerjasama antar mitra usaha dengan kesamaan porsi penyertaan modal, pembagian keuntungan dan pengelolaan kerja, (3) Syirkah al-a'mal, kerjasama dimana semua mitra usaha ikut memberikan jasa pada pelanggan, (4) Syirkah al-wujuh, kerjasama dimana mita usaha tidak memiliki investasi sama sekali.

Teknis perbankan yang diterapkan pada pembiayaan ini adalah sama halnya dengan pembiayaan mudharabah,menggunakan metode revenue sharing dikarenakan resiko yang ditanggung kecil. Jika mengunakan metode ini, pemilik dana tidak pernah rugi atau minimal bagi hasil $=0 .{ }^{19}$

Pembiayaan musyarakah dalam praktik perbankan diaplikasikan dalam hal pembiayaan proyek. Dalam hal ini nasabah yang dibiayai dengan bank sama-sama menyediakan dana untuk melaksanakan proyek tersebut. Keuntungan dari proyek di bagi sesuai dengan kesepakatan untuk bank setelah mengembalikan dana yang dipakai nasabah. Dalam hal ini dapat dijelaskan bahwa tinggi rendahnya nilai suatu pembiayaan musyarakah akan berpengaruh terhadap profitabilitas suatu bank. Sebab, dengan adanya pembiayaan musyarakah yang disalurkan kepada nasabah, bank mengharapkan akan mendapatkan keuntungan dan nisbah bagi hasil yang signifikan. Penyebab dari hubungan yang negatif antara pembiayaan musyarakah terhadap profitabilitas (ROA) suatu bank, yaitu karena nasabah yang mendapatkan pembiayaan musyarakah dari bank belum tentu nasabah tersebut akan mengembalikan dana yang didapat dari bank pada tahun yang sama, dan belum tentu semua nasabah taat dan tepat waktu dalam mengembalikan dana yang diperoleh dari bank, karena tidak menutup kemungkinan bahwa akan terjadi pengembalian pembiayaan yang kurang lancar atau bahkan macet, sehingga semakin tinggi kontribusi dana pada pembiayaan musyarakah maka akan menurunkan tingkat profitabilitas (ROA) suatu bank.

Hasil pengujian yang didapatkan pada uji $\mathrm{F}$ (simultan) diperoleh nilai $\mathrm{f}_{\text {hitung }}$ sebesar 7,952 yang lebih besar dari nilai $f_{\text {tabel }}$ sebesar 3,28 serta nilai signifikansi yaitu 0,002 lebih kecil dari 0,05 . Sehingga dalam pengujian secara bersama-sama (simultan) pada pembiayaan mudharabah dan pembiayaan musyarakah memberikan pengaruh yang positif dan siginifikan terhadap profitabilitas (ROA). Serta terdapat hubungan yang erat antara pembiayaan mudharabah dan pembiayaan musyarakah dengan profitabilitas (ROA) Bank Umum Syariah. Hal tersebut disebabkan karena masing-masing pembiayaan yang disalurkan kepada nasabah memberikan keuntungan kepada bank syariah. Pembiayaan mudharabah dan musyarakah memberikan keuntungan berupa nisbah (bagi hasil) dibagi diantara keduanya dengan porsi bagian sesuai dengan yang dipersyaratkan dalam akad. Hasil penelitian ini sejalan dengan

\footnotetext{
${ }^{18}$ Umam, Manajemen Perbankan Syariah, 2013, hlm. 32.

19 Permata, Yaningwati, dan Z.A, "ANALISIS PENGARUH PEMBIAYAAN MUDHARABAH DAN MUSYARAKAH TERHADAP TINGKAT PROFITABILITAS (RETURN ON EQUITY)," hlm. 4. 28
}

SHAFIN: Finance and Sharia Accounting Journal

Vol. 1 No. 1 Maret 2021 
Praktik Pembiayaan Mudharabah dan Musyarakah terhadap Profitabilitas Bank Umum Syariah di Indonesia hasil penelitian sebelumnya yang dilakukan oleh Romdhoni dan Yozika (2018) yang menyatakan bahwa pembiayaan mudharabah dan pembiayaan musyarakah secara bersamasama berpengaruh terhadap profitabilitas (ROA).

\section{PENUTUP}

\section{Kesimpulan}

Berdasarkan hasil pengujian pada penelitian yang sudah dibahas sebelumnya, maka dapat disimpulkan bahwa:

1. Pembiayaan mudharabah berpengaruh signifikan dan positif terhadap profitabilitas (ROA) Bank Umum Syariah di Indonesia pada periode 2017-2019 secara parsial.

2. Pembiayaan musyarakah berpengaruh signifikan dan negatif terhadap profitabilitas (ROA) Bank Umum Syariah di Indonesia pada periode 2017-2019 secara parsial.

3. Pembiayaan mudharabah dan pembiayaan musyarakah berpengaruh signifikan dan positif terhadap profitabilitas (ROA) Bank Umum Syariah di Indonesia pada periode 2017-2019 secara simultan.

\section{Saran}

Berdasarkan kesimpulan yang telah dipaparkan diatas, maka terdapat beberapa saran bagi perusahaan dan penelitian selanjutnya, yaitu sebagai berikut:

1. Bagi pihak bank hendaknya mampu meningkatkan minat nasabah pembiayaan mudharabah dan pambiayaan musyarakah untuk kebutuhan nasabah. Dengan demikian pihak bank diharapkan dapat meningkatkan kompetisinya di dunia perbankan Indonesia.

2. Bagi bank sebelum memberikan pembiayaan mudharabah dan pembiayaan musyarakah, hendaknya berhati-hati dalam memilih nasabah serta dapat menilai kemampuan usaha yang dibiayainya.

3. Bagi penelitian selanjutnya, sebaiknya diperluas kembali mengenai lingkup penelitian dengan meneliti beberapa faktor lain yang memungkinkan dapat mempengaruhi profitabilitas selain ROA (Return on Assets), yaitu ROE (Return on Equity),GPM (Gross Profit Margin), NPM (Net Profit Margin), FDR (Financing to Deposit Ratio) dan OPM (Margin Laba Operasional).

4. Bagi peneliti selanjutnya diharapkan dapat meneliti variabel lainnya yang berkaitan dengan profitabilitas suatu bank.

\section{DAFTAR PUSTAKA}

Ascarya. Bank Syariah Gambaran Umum. Jakarta: Bank Indonesia, 2005.

Dharma, Yulius, dan Ade Pristianda. "PENGARUH PEMBIAYAAN MUDHARABAH DAN MURABAHAH TERHADAP PROFITABILITAS (RETURN ON ASSETS) BANK PEMBIAYAAN RAKYAT SYARIAH DI INDONESIA 2012-2016." Jurnal Ekonomika Indonesia VII, no. 02 (Desember 2015): 5.

Fazriani, Anisya Dwi, dan Rimi Gusliana Mais. "Pengaruh Pembiayaan Mudharabah, Musyarakah, dan Murabahah terhadap Return On Asset melalui Non Performing Financing sebagai Variabel Intervening (pada Bank Umum Syariah yang Terdaftar diotoritas Jasa Keuangan)." Jurnal Akuntansi dan Manajemen 16, no. 01 (8 April 2019): 1-34. https://doi.org/10.36406/jam.v16i01.265.

Indriyanssyah Purba, Asra. "Pengaruh Perubahan Bank Umum Syariah Terhadap Minat Menabung di Bank Aceh Syariah Pada Masyarakat Kabupaten Aceh Tenggara." HUMAN FALAH 4, no. 1 (t.t.): Januari-Juni 2017.

Ismail. Perbankan Syariah. Jakarta, Indonesia: Kencana, 2011. 
Latif, Chefi Abdul. "PEMBIAYAAN MUDHARABAH DAN PEMBIAYAAN MUSYARAKAH DI PERBANKAN SYARIAH." Jurnal Ilmu Akuntansi dan Bisnis Syariah 2, no. 01 (Januari 2020): 14.

Marimin, Agus, dan Abdul Haris Romdhoni. "PERKEMBANGAN BANK SYARIAH DI INDONESIA." Jurnal Ilmiah Ekonomi Islam 1, no. 02 (10 Februari 2017). https://doi.org/10.29040/jiei.v1i02.30.

Nafik Hadi Ryandono, Muhamad, dan Rofiul Wahyudi. Manajemen Bank Islam: Pendekatan Syariah dan Praktek. Yogyakarta: UAD PRESS, 2018.

Nofinawati. "PERKEMBANGAN PERBANKAN SYARIAH DI INDONESIA." JURIS 14, no. 2 (Juni 2015): 169-83.

Notoatmojo, Muhammad Iqbal. "ANALISIS DAMPAK LIKUIDITAS TERHADAP PROFITABILITAS PADA BANK UMUM SYARIAH DI INDONESIA PERIODE 2010 -2016." Equilibrium: Jurnal Ekonomi Syariah 6, no. 1 (29 Juli 2018): 19. https://doi.org/10.21043/equilibrium.v6i1.3254.

Permata, Russely Inti Dwi, Fransisca Yaningwati, dan Zahroh Z.A. "ANALISIS PENGARUH PEMBIAYAAN MUDHARABAH DAN MUSYARAKAH TERHADAP TINGKAT PROFITABILITAS (RETURN ON EQUITY)." Jurnal Administrasi Bisnis (JAB) 12, no. 1 (Juli 2014): 9.

Puteri, Deasy Rahmi, Inten Meutia, dan Emylia Yuniartie. "PENGARUH PEMBIAYAAN MUDHARABAH,MUSYARAKAH, MURABAHAH, ISTISHNA DAN IJARAH TERHADAP PROFITABILITAS PADA BANK UMUM SYARIAH DI INDONESIA." Jurnal Penelitian dan Pengembangan Akuntansi 8, no. 1 (Januari 2014): 24.

Refinaldy, Aditya, Septarina Prita Dania Sofianti, dan Yosefa Sayekti. "Pengaruh Tingkat Pembiayaan Musyarakah Dan Pembiayaan Mudharabah Terhadap Tingkat Profitabilitas Bank Syariah." Jurusan Akuntansi, Fakultas Ekonomi, Universitas Jember, t.t.

Sindy Pastiani, Alfina. "Perkembangan Perbankan Syariah di Indonesia." Fakultas Ekonomi, Manajemen Universitas Djuanda, November 2019.

"Statistik Perbankan Syariah," t.t., Januari 2020.

Umam, Khaerul. Manajemen Perbankan Syariah. Bandung: Pustaka Setia, 2013.

Yaya, Rizal, Aji Erlangga Martawireja, dan Ahim Abdurahim. Akuntansi Perbankan Syariah Teori dan Praktik Kontemporer Berdasarkan PAPSI 2013. Edisi 2. Jakarta: Salemba Empat, 2014. 